\title{
Economic Recession Coping Strategies in Nigeria: The Case of Rural Dwellers in Moro Local Government Area of Kwara State
}

\section{Ifabiyi JO1* and Banjoko IK ${ }^{2}$}

${ }^{1}$ Department of Agricultural Extension and Rural Development, University of Ilorin, Ilorin, Nigeria

${ }^{2}$ Department of Agricultural Technology, Kwara State Polytechnic, Ilorin, Nigeria

\begin{abstract}
This study focused on the assessment of economic recession coping strategies in Moro local government area in Kwara state, Nigeria. Seventy rural dwellers were randomly selected for this study. Data were obtained using a structured questionnaire to elicit information on respondents' socioeconomics characteristics, the sources of information, the perceived effects of economic recession on rural dwellers, the economic recession coping strategies and the perceived causes of economic recession. Result reveals that the mean age of the rural dwellers 51.8 years, $61.4 \%$ were married, $27.1 \%$ had tertiary education and $32.9 \%$ were farmers. The average monthly income of the rural dwellers were 12204.29 Naira (equivalent to 33 US dollars per month). The highest ranked perceived effects of economic recession were increased in prices of goods and services and that economic recession has encourage many rural dwellers to go back to farming (4.60). The coping strategies were working harder (2.73), changing life style (2.51) and borrowing money from family members and friends (2.31). Neglect of agriculture (4.67) and over dependence on crude oil (4.50) were the perceived causes of economic recession by the respondents. The result of PPMC reveals that there was a significant relationship between the coping strategies of the rural dwellers and their educational level $(r=0.604 ; p=0.049)$. The study recommends that there is need for government to make palliative measures that will cushion the effects of economic recession on the rural dwellers.
\end{abstract}

Keywords: Economic recession; Coping strategies; Rural dwellers; GDP growth; Unemployment

\section{Introduction}

Agriculture is the main source of employment in Nigeria as it provide livelihood to about $75 \%$ of the population. Majority of Nigerian population live in the rural areas. The ongoing economic recession has made life difficult for most Nigerians. The country is in a difficult situation as a lots of Nigerians are jobless, poverty level and crime rate has increased and there is high food insecurity in the country.

In economics, a recession is a negative growth for two consecutive quarters. For a layman's understanding, a recession is a period of general economic slowdown. It is also a business cycle contraction which results in a general slowdown in economic activity. During this economic recession in Nigeria, there is decrease in sales of goods and services, high inflation rates, increase in unemployment, high crime rate, budget deficit in government spending and decline in the stock market etc.

According to National Bureau of Statistics [1], Nigeria's GDP at constant basic prices, contracted in the second quarter of 2016 by 2.06 per cent after shrinking 0.36 in the first quarter. RTC (2016) also, reported that the Nigerian economy has recorded two consecutive quarters of economic contraction, in the First Quarter of 2016, GDP growth was negative $(-0.36 \%)$ and recently released the Second Quarter of 2016 data reflects a larger contraction $(-2.06 \%)$.The economic contraction is fairly broad and includes both oil and non-oil sectors. The oil sector contracted by $17.48 \%$ and non-oil sectors by $0.38 \%$. Some of the reasons Nigeria went into economic recession were Oil price decline of 56.39\% from 2014's peak in the global oil market from $\$ 100$ per barrel to $\$ 50$, Sharp oil production drop of $26.3 \%$, Partly due to underinvestment in the oil and gas sector and compounded by Niger Delta Avengers sabotage, bad leadership fiscal leakages and corruption [2]. The Nigeria vanguard newspaper (2017) reports the UNESCO and the Human Development Index of UNDP, according to the report Nigeria has the highest number of children out of school, Human
Development Index of UNDP, Nigeria ranked 152 out of 188 countries and is the lowest among OPEC countries and life expectancy at birth is

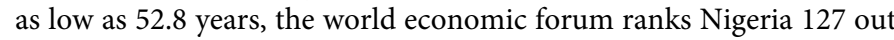
of 138 on global competitiveness index and the global terrorism index ranked Nigeria $3^{\text {rd }}$ after Iraq and Afghanistan vanguard newspaper (2017). The effects of this economic downturn are already being felt by all and sundries in the form of unpaid salaries, inability to pay rent, inability to pay children school fees and even inability to feed [3].

\section{Theoretical Background}

Coping strategies refer to a set of measures adopted to attempt to meet the physiological, social, economic and political needs of everyday life of a person. Coping strategies are responses to an immediate and irregular decline in access to resources (FAO, 1997). The measures or actions that is taken could also be termed techniques or behaviours. These techniques or behaviours are called coping strategies [4].

Folkman [5] conceptualized two broad response dimensions among people facing stress: emotion focused coping involves modifying one's own feelings and controlling distress, and problem-focused coping activities are aimed at changing the stressful situation. For this study problem-focuesd coping strategies is applicable. The problem focused coping strategy is about trying to deal with the stressor itself so as to avoid the stressful situations. It aims at changing the nature

*Corresponding author: Ifabiyi JO, Department of Agricultural Extension and Rural Development, University of Ilorin, PMB 1515, Ilorin, Nigeria, Tel: +2348061246270; E-mail: oluwole4love@yahoo.com

Received November 27, 2017; Accepted January 18, 2018; Published January 25, 2018

Citation: Ifabiyi JO, Banjoko IK (2018) Economic Recession Coping Strategies in Nigeria: The Case of Rural Dwellers in Moro Local Government Area of Kwara State. J Glob Econ 6: 279. doi: 10.4172/2375-4389.1000279

Copyright: @ 2018 Ifabiyi JO, et al. This is an open-access article distributed unde the terms of the Creative Commons Attribution License, which permits unrestricted use, distribution, and reproduction in any medium, provided the original author and source are credited. 
of the problem by taking direct actions to control the situation. This coping technique is more common when people believe their action can affect the stressor. For instance during economic recession rural dwellers acquires new skills, cultivate more lands, take additional jobs, change life styles and cut spendings etc. Coping, on its side, consists of cognitive and behavioral efforts to manage external or internal demands (and conflicts between them) that are appraised as taxing or exceeding the resources of the person.

Understanding the effects of economic recession on rural dwellers and copying strategies used are also important. Also, studies of this type are needed to identify interventions that complement rural dwellers' own strategies so as to identify more coping strategies and to cushion the effects of economic recession on the rural dwellers. The main objective of this study was to assess the economic recession coping strategies of rural farmers in Moro local government area of Kwara State, Nigeria.

\section{The Specific Objectives}

1. Ascertain the socio-economic characteristics of respondents

2. Determine the sources of information of the respondents.

3. Assess the perceived effects of economic recession on the respondents.

4. Investigate the respondents' economic recession coping strategies.

5. Determine the perceived causes of economic recession.

\section{Hypotheses}

These null hypotheses were tested

Ho $_{1}$ : There is no significant relationship between some selected socioeconomic characteristics and their coping strategies.

$\mathbf{H o}_{2}$ : There is no significant relationship between some their coping strategies and the perceived effects of economic recession.

\section{Methodology}

The study was carried out in Moro local government area of Kwara state, Nigeria. Moro local government area has its headquarter in Bode Saadu. It has an area of $3,272 \mathrm{~km}^{2}$ and a population of 108,792 at the 2006 census. The people are predominantly farmers and traders.

The population for the study consist of seventy rural dwellers randomly selected from four rural communities which are Shao, Ara, Balapa, and Magaji. To determine the perceived effects of economic recession on rural dwellers, a five point likert-type were assigned and scored as follows: Strongly Agreed $(\mathrm{SA})=5$, Agreed $(\mathrm{A})=4$, Undecided $(\mathrm{U})=3$, Disagreed $(\mathrm{D})=2$, and Strongly Disagreed $(\mathrm{SD})=1$. The coping strategy, a three point likert scale were used as follows: Not used $=1$, Rarely used $=2$ and Always Used $=3$. The perceived causes of economic recession were measured using a five point likert scale of Strongly Agreed $(S A)=5$, Agreed $(A)=4$, Undecided $(U)=3$, Disagreed $(D)=2$, and Strongly Disagreed $(\mathrm{SD})=1$. All the 70 copies of the questionnaires distributed were returned. Descriptive statistics such as frequency counts, percentage and means were used to analyze the finding of the study. Pearson product moment correlation (PPMC) was used to test the hypothesis. The validity of the instrument was tested, Data collected were analyzed and the internal Consistency of the instrument was determined using Cronbach alpha index of 0.79 which in agreement with Olaniyi [6] that 0.7 reliability coefficient or above is an acceptable reliable value.

\section{Results and Discussion}

\section{Respondents' socioeconomic characteristics}

The results from Table 1 reveals that $57.1 \%$ of the respondents

\begin{tabular}{|c|c|c|c|}
\hline Variables & Frequency & Percentage & Mean \\
\hline \multicolumn{4}{|l|}{ Gender } \\
\hline Male & 30 & 42.9 & \\
\hline Female & 40 & 57.1 & \\
\hline \multicolumn{3}{|l|}{ Age } & 51.8 \\
\hline $20-40$ & 17 & 24.3 & \\
\hline $41-60$ & 33 & 47.1 & \\
\hline$\geq 61$ & 20 & 28.6 & \\
\hline Total & 70 & 100.0 & \\
\hline \multicolumn{4}{|l|}{ Marital status } \\
\hline Single & 6 & 8.6 & \\
\hline Married & 43 & 61.4 & \\
\hline Separated & 3 & 4.3 & \\
\hline Widowed & 12 & 17.1 & \\
\hline Divorced & 6 & 8.6 & \\
\hline Total & 70 & 100.0 & \\
\hline \multicolumn{4}{|l|}{ Educational level } \\
\hline No formal Education & 17 & 24.3 & \\
\hline Primary & 16 & 22.9 & \\
\hline Secondary & 18 & 25.7 & \\
\hline Tertiary & 19 & 27.1 & \\
\hline Total & 70 & 100.0 & \\
\hline \multicolumn{4}{|l|}{ Religious affiliate } \\
\hline Christianity & 18 & 25.7 & \\
\hline Islam & 51 & 72.9 & \\
\hline Traditional & 1 & 1.4 & \\
\hline Total & 70 & 100.0 & \\
\hline \multicolumn{4}{|l|}{ Occupation type } \\
\hline Farming & 23 & 32.9 & \\
\hline Agro processing & 11 & 15.7 & \\
\hline Trading & 18 & 25.7 & \\
\hline Artisan & 1 & 1.4 & \\
\hline Civil servant & 7 & 10.0 & \\
\hline Others & 10 & 14.3 & \\
\hline Total & 70 & 100.0 & \\
\hline \multicolumn{3}{|l|}{ Income } & $\begin{array}{l}12204.29 \text { Naira } \\
\text { (US } 33 \text { dollar) }\end{array}$ \\
\hline$\leq 10,000$ & 42 & 60.0 & \\
\hline $11000-20,000$ & 18 & 25.7 & \\
\hline $21,000-30,000$ & 8 & 11.4 & \\
\hline$\geq 31,000$ & 2 & 2.9 & \\
\hline Total & 70 & 100.0 & \\
\hline \multicolumn{3}{|c|}{ Years of farming experience } & 18.82 \\
\hline$\leq 10$ & 24 & 34.3 & \\
\hline $11-20$ & 21 & 30 & \\
\hline $21-30$ & 16 & 22.9 & \\
\hline$\geq 30$ & 9 & 12.9 & \\
\hline Total & 70 & 100.0 & \\
\hline \multicolumn{3}{|l|}{ Household size } & 4.84 \\
\hline$\leq 5$ & 42 & 60 & \\
\hline$\geq 6$ & 28 & 40 & \\
\hline \multicolumn{4}{|l|}{ Source of credit } \\
\hline Own saving & 28 & 40.0 & \\
\hline Cooperative society & 15 & 21.4 & \\
\hline Borrow & 19 & 27.1 & \\
\hline Government grant & 8 & 11.4 & \\
\hline
\end{tabular}

Table 1: Socioeconomics characteristics of rural dwellers. 
were female while $42.9 \%$ were male, the average age of the respondents were 51.8 years. $64 \%$ were married, 17.1 were widowed and 4.3 were separated. $27.1 \%$ had tertiary education, $25.7 \%$ had secondary education while $24.3 \%$ had no formal education. $72.9 \%$ were Islam worshippers while 25.7 were Christians. $32.9 \%$ were farmers while $25.7 \%$ were traders. The average income of the respondents was 12204.29 naira. The average years of experience were 18.82 years and the average household size was 4.84 .

\section{The source of information}

Table 2 reveals the sources of information of the rural dwellers, the most important source of information was family members and neighbor/friends respectively. This implies that there is strong network among family members and neighbors in sharing information. Radio/ television, mobile/cell phone and Community group/Associations was ranked $3^{\text {rd }}, 4^{\text {th }}$ and $5^{\text {th }}$ respectively. This result is in agreement with the result of Ifabiyi et al. [7] who reported that family and neighbors were very effective social networking in the use of irrigation among farmers in North central Nigeria.

\section{The Perceived effects of economic recession on rural farming households}

Result in Table 3 reveals that increase in price of goods and services and Economic recession encourages many people to go back to farming (4.60) respectively, this implies that despite the

\begin{tabular}{|l|c|c|c|c|}
\hline Source of information & Yes & No & Mean & Rank \\
\hline Extension agents/services & 2.9 & 97.1 & 1.03 & 9 \\
\hline Radio/ Television & 91.4 & 8.6 & 1.91 & 3 \\
\hline Cooperative society & 30.0 & 70.0 & 1.30 & 6 \\
\hline Family members & 94.3 & 5.7 & 1.94 & 1 \\
\hline Mobile/Cell phone & 55.7 & 44.3 & 1.56 & 4 \\
\hline Newspaper/ magazines & 18.6 & 81.4 & 1.19 & 7 \\
\hline NGOs & 5.7 & 94.3 & 1.06 & 8 \\
\hline Community group/Associations & 41.4 & 58.6 & 1.41 & 5 \\
\hline Neighbor/Friend & 94.3 & 5.7 & 1.94 & 1 \\
\hline
\end{tabular}

Table 2: Source of information. negative effects of economic recession, the positive effect is that it has encouraged many rural dwellers to go back to Agriculture so as to be food secured. Economic recession has increased the number of people who are beggars/vulnerable/dependants (4.53), It affects small scale rural business (4.43), There is increases in crime rate (4.43) and there is reduction in quality and quantity of food consumed by the household. (food insecurity) (4.39).

\section{Rural dwellers coping strategies}

The result in Table 4 reveals that Borrowing money from family members and friends (2.31), Accepting a low paying job as a short term solution (2.09), Operation a small scale business (2.29), Life style changes, by looking for cheaper alternatives and prioritize spending (2.51), Selling property/ farm harvest/livestock (2.14), Acquiring new skills (2.06), Acquiring more land for crop cultivation (2.23), Working harder (2.73) were important coping strategies.

\section{The perceived causes of economic recession}

The result from Table 5 reveals that neglect of agriculture (4.67) was ranked $1^{\text {st }}$ as the perceived causes of economic recession by the respondents. Over dependence on crude oil (4.50), Farmers/herdsmen conflicts and High inflation rate (4.47), Corruption (4.46) and Poor government policies and poor economic planning (4.43). The result reveals that agriculture has neglected, most young Nigerian preferred white collar jobs that are not readily available due to dwindling economy and this may be one of the factors responsible for the latest economy recession in Nigeria. Also the result reveals that over dependence on crude oil was one of the perceived causes of economy recession in Nigeria, since the discovery of crude oil, agriculture and other sources of revenue has been abandon for crude oil making Nigerian economy a mono-economy. Hence, there is need for government to diversify the economy so that every sectors will be productive. The result is in agreement with the study of Ogbimi [8] who reported that poor economic policies and corruption will make an economy to be stressed.

The result in Table 6 reveals that there is a significant relationship between their coping strategies educational level $(r=0.604 ; p=0.049)$

\begin{tabular}{|c|c|c|c|c|c|c|c|}
\hline Effects & SD & D & $\mathbf{U}$ & A & SA & Mean & Rank \\
\hline Economic recession encourages many people to go back to farming & & & 2.9 & 34.3 & 62.9 & $4.60^{*}$ & 1 \\
\hline It causes high unemployment due to job losses & 1.4 & 2.9 & & 50.0 & 45.7 & $4.36^{*}$ & 8 \\
\hline It affects small scale rural business & 1.4 & & & 51.4 & 47.1 & $4.43^{*}$ & 4 \\
\hline $\begin{array}{l}\text { There are high incidence of frictions (conflicts) among rural household } \\
\text { due to no or inadequate income }\end{array}$ & & 4.3 & 5.7 & 54.3 & 35.7 & $4.21^{*}$ & 10 \\
\hline Leads to inability to pay for public utilities like electricity and water, bills & & & & 62.9 & 37.1 & $4.37^{*}$ & 7 \\
\hline $\begin{array}{l}\text { There is reduction in quality and quantity of food consumed by the } \\
\text { household.(food insecurity) }\end{array}$ & & & & 61.4 & 38.6 & $4.39^{*}$ & 6 \\
\hline Reduces the value of the local currency (naira) & & & 7.1 & 62.9 & 30.0 & $4.22^{*}$ & 9 \\
\hline Leads to high rural-urban migration & & 4.3 & 4.3 & 72.9 & 18.6 & $4.06^{*}$ & 14 \\
\hline Leads to increase in wage demand of farm labourers & & 5.7 & 5.7 & 60.0 & 28.6 & $4.11^{*}$ & 12 \\
\hline There is increase in price of goods and services & & 1.4 & & 35.7 & 62.9 & $4.60^{*}$ & 1 \\
\hline $\begin{array}{l}\text { There is increases in crime rate (arm robberies, kidnapping, stealing, } \\
\text { prostitutions etc.) }\end{array}$ & & 2.9 & 1.4 & 45.7 & 50.0 & $4.43^{*}$ & 4 \\
\hline $\begin{array}{l}\text { leads to poor health conditions (depression \& emotional trauma) as } \\
\text { rural people cannot afford the cost of good health care services }\end{array}$ & 2.9 & 2.9 & 4.3 & 55.7 & 34.3 & $4.16^{*}$ & 11 \\
\hline Increases economic pressure on the household heads & & 4.3 & & 78.6 & 17.1 & $4.09^{*}$ & 13 \\
\hline Increases rural household debts & & 7.1 & 2.9 & 61.4 & 28.6 & $4.11^{*}$ & 11 \\
\hline $\begin{array}{l}\text { Economic recession has increased the number of people who are } \\
\text { beggars / vulnerable / dependants }\end{array}$ & & 2.9 & 1.4 & 35.7 & 60.0 & $4.53^{*}$ & 3 \\
\hline
\end{tabular}




\begin{tabular}{|c|c|c|}
\hline \multicolumn{2}{|l|}{ Coping strategies } & NOT USE \\
\hline \multicolumn{2}{|l|}{ Receiving government interventions } & 64.3 \\
\hline \multicolumn{2}{|l|}{ Borrowing money from family members and friends } & 7.1 \\
\hline \multicolumn{2}{|l|}{ Accepting a low paying job as a short term solution } & 27.1 \\
\hline \multicolumn{2}{|l|}{ Operation a small scale business } & 14.3 \\
\hline \multicolumn{2}{|c|}{$\begin{array}{l}\text { Life style changes, by looking for cheaper alternatives and prioritize } \\
\text { spending }\end{array}$} & 2.9 \\
\hline \multicolumn{2}{|l|}{ Selling property/ farm harvest/livestock } & 20.0 \\
\hline \multicolumn{2}{|l|}{ Acquiring new skills } & 28.6 \\
\hline \multicolumn{2}{|l|}{ Acquiring more land for crop cultivation } & 22.9 \\
\hline \multicolumn{2}{|l|}{ Working harder } & 2.9 \\
\hline \multicolumn{2}{|l|}{ Depends on gifts/remittance. } & 47.1 \\
\hline \multicolumn{3}{|l|}{ Note: *Coping Strategy. } \\
\hline \multicolumn{3}{|c|}{ Table 4: Rural dwellers coping } \\
\hline Causes of economic recession & Mean & Rank \\
\hline Over dependence on crude oil (mono-economy) & 4.50 & 2 \\
\hline Corruption & 4.46 & 4 \\
\hline Neglect of agricultural sector & 4.67 & 1 \\
\hline High/over importation of goods & 4.09 & 6 \\
\hline Climate change & 3.76 & 10 \\
\hline Insecurity and pipeline vandalism & 3.89 & 8 \\
\hline High unemployment rate & 3.99 & 7 \\
\hline High interest rate & 3.86 & 9 \\
\hline Poor government policies and poor economic planning & 4.43 & 5 \\
\hline Farmers/herdsmen conflicts & 4.47 & 3 \\
\hline High inflation rate ( rise in price of goods and services) & 4.47 & 3 \\
\hline
\end{tabular}

Table 5: The perceived causes of economic recession.

\begin{tabular}{|c|c|c|c|}
\hline Variable & r value & p value & Decision \\
\hline Gender & -0.420 & 0.198 & Not significant \\
\hline Age & 0.094 & 0.784 & Not significant \\
\hline Education level & $0.604^{\star}$ & 0.049 & Significant \\
\hline Occupation type & 0.192 & 0.572 & Not significant \\
\hline Income & 0.563 & 0.071 & Not significant \\
\hline Experience & 0.101 & 0.768 & Not significant \\
\hline
\end{tabular}

Note: * Correlation is significant at the 0.05 level (2-tailed).

Table 6: Socio-economics attributes of the respondents on the economic recession coping strategies.

significant at $0.05 \%$. This study therefore rejects the null hypothesis one. This implies that the educated rural dwellers will be informed, education will make them have knowledge of different coping strategies and it will also influence their decisions.

The result on Table 7 reveals that there is no significant relationship between their coping strategies and the perceived effects of economic recession, this implies that the personal coping strategies may not effectively cushion the effects of economic recession on the rural dwellers. Hence, government should provide palliate measures. The null hypothesis that there is no significant relationship between their coping strategies and the perceived effect of economic recession is therefore accepted.

\section{Conclusion and Recommendations}

The study reveals that family members and neighbor/friends were the most important source of information. The study reveals

\begin{tabular}{|c|c|c|c|}
\hline Variable & r value & p value & Decision \\
\hline Perceived effect & -0.95 & 0.436 & Not significant \\
\hline
\end{tabular}

Table 7: Correlation between the coping strategy and the perceived effect of economic recession.

that economic recession has encourage many people to go back to farming in order to be food secured and as a source of livelihood. The economic recession coping strategies of the rural dwellers were borrowing money from family members and friends, accepting a low paying job as a short term solution, operation a small scale business, life style changes, by looking for cheaper alternatives and prioritize spending, selling property/ farm harvest/livestock, acquiring new skills, acquiring more land for crop cultivation, working harder and depends on gifts/remittance. Neglect of agriculture and overdependence on crude oil were perceived as the reasons why Nigeria economy went into recession. There is a significant relationship between the coping strategies of the respondents and their educational level.

The study recommends that there should be provision of information on the various economic recession strategies to the rural dwellers. Also, there is need for government to provide palliative measures that will cushion the effects of economic recession on the rural dwellers and government should make every effort to move Nigerian economy out of the recession immediately.

\section{References}

1. National Bureau of Statistics (2016) Economic recession worse expected. Vanguard Newspaper, September 1.

2. RTC Advisory Services (2016) Nigeria's Economy and Recession: Outlook for 2017, Lagos, Nigeria

3. The Nigerian Vanguard (2017) Nigerian economy retrieve on May 26, 2017.

4. Food and Agriculture Organization (FAO) (1997) Agriculture, food and nutrition for Africa. FAO Publishing Management Group, Rome.

5. Folkman S (1984) Stress, Appraisal and Coping. Springer.

6. Olaniyi ON (2016) Small and Medium enterprises Managers ratings of skills needed by business education graduates for entrepreneurial success in Ondo Ekiti States.

7. Ifabiyi JO, Adesiji GB, Komolafe SE, Ajibola BO (2014) Irrigation farmers motivation for Participating in social networking in North Central Nigeria. Ethiopian Journal of Environmental Studies and Management 7: 572-580.

8. Ogbimi FE (2007) Solution to mass unemployment in Nigeria. Obafem Awolowo University Press Limited. 